\title{
Investigating the Effect of Titanium Dioxide (TiO2) Pollution on the Performance of the Mono-crystalline Solar Module
}

\author{
Zeki Ahmed Darwish ${ }^{1,2}$, K. Sopian ${ }^{1}$, Hussein A Kazem ${ }^{3}$, M.A. Alghoul ${ }^{4}$ and \\ Hussain Alawadhi ${ }^{5}$ \\ ${ }^{1}$ Solar Energy Research Institute (SERI), Universiti Kebangsaan Malaysia, Bangi 43600 \\ Selangor, Malaysia \\ ${ }^{2}$ Ministry of Education, United Arab Emirates, Dubai PO. Box 3962 \\ ${ }^{3}$ Faculty of Engineering, Sohar University PO Box 44, Sohar, PCI 311 Oman \\ ${ }^{4}$ Energy and Building Research Center, Kuwait Institute for Scientific Research, Safat 13109, \\ Kuwait \\ ${ }^{4}$ Center of Research Excellence in Renewable Energy (CoRERE), King Fahd University of \\ Petroleum and Minerals (KFUPM), Dhahran 31261, Saudi Arabia \\ ${ }^{5}$ Research Center for Advanced Materials, University of Sharjah, PO Box 27272 United Arab \\ Emirates
}

\begin{abstract}
This paper presents a study of titanium oxide $\mathrm{TiO}_{2}$ as one of the components of dust pollution affecting the PV performance. This pollutant can be found in various quantities in different locations around the world. The production of energy by different types of photovoltaic systems is very sensitive and depends on various environmental factors. Dust is one of the main contributing factors, yet the type of the dust is often neglected when studying the behaviour of the solar panel. In this experimental work we have studied the performance of the monocrystalline solar module as affected by the density of $\mathrm{TiO}_{2}$. The reduction of the PV module power caused by titanium dioxide under various mass densities was investigated. The results showed that the $\mathrm{TiO}_{2}$ has a significant effect on the PV output power. The dust density varied between $0-125 \mathrm{~g} \cdot \mathrm{m}^{-2}$. The corresponding reduction of the PV output power increased from 0 to $86.7 \%$. This is based on various influencing parameters such as: short circuit current $\left(\mathrm{I}_{\mathrm{sc}}\right)$, maximum current $\left(\mathrm{I}_{\mathrm{m}}\right)$, open circuit voltage $\left(\mathrm{V}_{\mathrm{oc}}\right)$, maximum voltage $\left(\mathrm{V}_{\mathrm{m}}\right)$, maximum power $\left(\mathrm{P}_{\mathrm{m}}\right)$ and efficiency (E). Two functions are proposed as a mathematical model in order to explain this behaviour, namely the exponential and Fourier functions. The coefficients of all general models are valid for this type of dust with a density value ranging from $0-125 \mathrm{~g} \cdot \mathrm{m}^{-2}$.
\end{abstract}

Keywords: Titanium dioxide, dust effect, short circuit current, open circuit voltage, maximum power, fill factor

*Corresponding author. Tel.: +0060389118023; fax: +0060389118574. E-mail address:

ksopian@ukm.edu.my (K. Sopian) 


\section{Introduction}

Numerous technologies are currently used in order to harness solar radiation into suitable energy in the form of heat or electricity. Photovoltaic (PV) and solar thermal power (CSP) are the main technology systems used in order to convert light into electricity. An efficient application of this technology has a significant potential in both improving the economy and reducing pollution [1]. It has been widely acknowledged that photovoltaic power is closely linked to the use of solar energy for the production of electricity on a global scale. One of the main aspects to consider prior to introducing this type of technology to the market is represented by the efficiency of the solar cell. Extensive research is currently being conducted in order to improve the efficiency of the solar for future market use. Furthermore, a gradual improvement has been observed in relation to the efficiency of the monocrystalline silicon solar cell on an annual basis, from only $15 \%$ in the $1950 \mathrm{~s}$ to $17 \%$ in the $1970 \mathrm{~s}$ and a potential to increase up to $28 \%$ nowadays. According to Zhao et al. [2] photovoltaic performance is highly dependent on external conditions such as wind, temperature, irradiation and dust pollution. Furthermore, dust is also known to affect photovoltaic performance considering that it may prevent radiations from reaching the photovoltaic module [3]. Previous studies about the effects of dust on PV and solar thermal panels date back to over seventy years ago and focus on the thermal cells and the effect of dust on the reflectance of mirrors [4]. For instance, Sayigh who is credited as a pioneer in the Gulf region conducted a detailed investigation on the effect of dust on solar flat-plate collectors. The experiments included seven flat-plate collectors arranged in pairs and subjected to various inclinations of $0^{\circ}, 30^{\circ}$ and $60^{\circ}$ respectively, with the seventh collector inclined vertically at $90^{\circ}$. In the case of each pair, one collector was cleaned regularly while the other was left undisturbed [5]. The amount of solar energy absorbed by the unclean plates was computed and subsequently compared to the values obtained in the case of the clean plates. Within this context, a dusty collection of approximately $2.5 \mathrm{~g} / \mathrm{m}^{2} /$ day was recorded between the months of April and June. Moreover, Sayigh et al. [6] analysed the effect of dust accumulation on tilted glass plates in Kuwait. Within the framework of their study, a plate transmittance reduction from $64 \%$ to $17 \%$ was observed in the case of tilt angles ranging from $0^{\circ}$ to $60^{\circ}$ following 38 days of exposure. As indicated by the horizontal collector, the useful energy gain was further reduced by $30 \%$ after 3 days of dust accumulation. Monto and Rohit classified the research exploring the effects of dust on the PV performance into two phases: the first phase appraising 
the research conducted between 1940 and 1990 and the second phase appraising the research conducted between 1990 and 2010. A critical assessment of the research conducted during phase one was performed in order to evaluate the dust (pollution) level and composition at the location of the solar collector over the course of the experimental study. Very little investigation was conducted on the typical characteristics of dust itself, such as type, composition, accumulation rate and fill factor. The second phase refers to the salient limitations which still need to be overcome within the framework of this research prior to the integration thereof in the PV system design, such as optical and electro-chemical properties [7]. Although many types of dust and pollutants have been formerly studied, there are still certain types whose effects are yet to be explored. Kaldellis et al. [8] conducted a systematic experimental study of the different type of pollutions such as red soil, limestone and ash. The results indicated that the highest reduction was caused by the deposition of red soil, limestone and ash, respectively. Hussein et al. [9] studied the effects of air pollution on the performance of the PV module using red soil, ash, sand, calcium carbonate and silica, and it was found that the ash pollutant was the type of dust exerting the most significant impact on the PV module voltage. The highest value of PV voltage reduction of $25 \%$ was reported when ash was used. A comprehensive review of power loss due to soiling and the impact of dust on the use of solar energy was introduced by various researchers $[10,11,12,13]$. In recent years, human activities have caused serious environmental problems, such as the ozone hole, urban smoke and increased atmospheric pollution. A limited amount of information is provided about the side effects of air pollution, and in particular about the degraded photovoltaic performance due to the deposition of solid particles [14]. The effects associated with dust pollution are strongly correlated with the environment in which the PV system is installed and the local conditions thereof, such as climate. For this reason, there is no general model to be applicable in all cases. Previous studies have indicated titanium oxide as one of the dust components in the United Arab Emirates and four other locations [15]. This study focuses on the effect of titanium oxide on the mono crystalline module performance and proposes a simple mathematical model for the short circuit current $\left(\mathrm{I}_{\mathrm{sc}}\right)$, maximum current $\left(\mathrm{I}_{\mathrm{m}}\right)$, open circuit voltage $\left(\mathrm{V}_{\mathrm{oc}}\right)$, maximum voltage $\left(\mathrm{V}_{\mathrm{m}}\right)$, maximum power $\left(\mathrm{P}_{\mathrm{m}}\right)$ and efficiency (E). 


\section{Methodology}

This section of the paper will detail the methodology used in order to investigate the effect of titanium oxide on the PV panel. Firstly, the set-up of the system which includes the solar simulator, data-acquisition, solar panel and parameters will be presented. This is subsequently followed by some samples being examined using a Maya2000Pro spectrometer in order to measure the transmittance and reflectivity coefficients. These are then examined using an electron microscope (SEM) in order to identify the size of the particle. Finally, an experimental verification was conducted in order to assess the relationship between the density of mass and the decrease in current, voltage, power and efficiency.

Solar simulator

The solar simulator consists of 23 units of halogen tungsten lamps with an output power of $500 \mathrm{~W}$. The lamps are distributed into nine columns with each column (1, $3,5,7$ and 9) containing 3 lamps and with columns $(2,4,6,8)$ containing 2 lamps. The design of a sun simulator was based on a previous research on the development of the solar simulator $[16,17]$. The lamps consume $11.5 \mathrm{~kW}$ and the intensity of the solar irradiance has been controlled by nine voltage controllers with a capacity of $2 \mathrm{KVA}, 8 \mathrm{Amp}$. The results were obtained from one module at $583 \mathrm{~W} / \mathrm{m}^{2}$ with an error of $3.89 \%$ in record reading and a distance of $120 \mathrm{~cm}$ between the solar simulator and the PV module.

PV Module

A monocrystalline solar module with 40 solar cells was used in this research. Table 1 illustrates the module specifications at the technical standard test conditions of $\mathrm{AM}=1.5, \mathrm{~S}=1000 \mathrm{~W} / \mathrm{m}^{2}$ and $\mathrm{T}_{\mathrm{c}}=25^{\circ} \mathrm{C}$.

Table 1: Technical characteristics of the PV module

\begin{tabular}{|l|l|}
\hline \multicolumn{2}{|l|}{ Copex Solar: Model M100 } \\
\hline Peak Power & $100 \mathrm{~W}_{\mathrm{P}}$ \\
\hline Power Tolerance & $\pm 5 \mathrm{~W}$ \\
\hline Voltage $\left(\mathrm{V}_{\mathrm{mp}}\right)$ & $19.6 \mathrm{~V}$ \\
\hline Current $(\mathrm{Imp})$ & $5.11 \mathrm{~A}$ \\
\hline
\end{tabular}




\begin{tabular}{|c|c|}
\hline $\begin{array}{lll}\text { Open } & \text { Circuit } & \text { Voltage } \\
\left(\mathrm{V}_{\mathrm{oc}}\right) & & \end{array}$ & $24.8 \mathrm{~V}$ \\
\hline $\begin{array}{lll}\text { Short } & \text { Circuit } & \text { Current } \\
\left(\mathrm{I}_{\mathrm{sc}}\right) & & \end{array}$ & $5.56 \mathrm{~A}$ \\
\hline Weight & $11 \mathrm{Kg}$ \\
\hline Dimensions & $1335 \times 547 \times 40 \mathrm{~mm}$ \\
\hline
\end{tabular}

Data acquisition

The $3711 \mathrm{~A}$ is a programmable DC electronic load, capable of supporting up to 360 $\mathrm{W}, 360 \mathrm{~V}$ and 30A. The software for this device was developed by Ross Bunker (Copyright@2012 Gratings, Inc.) in order to read the main electrical parameters of the solar module such as the short-circuit $I_{s c}$, the open-circuit voltage $V_{o c}$, the maximum power $\mathrm{P}_{\mathrm{m}}$, the fill factor $\mathrm{FF}$, the shunt resistance $\mathrm{R}_{\mathrm{sh}}$ and the series resistance $\mathrm{R}_{\mathrm{s}}$. In the final setup the data acquisition was connected to the computer and also directly to the PV panel, which was located under the solar simulator with a zero tilt angle. The test started with the study of a clean PV module followed by the gradual addition of $15 \mathrm{~g}$ of $\mathrm{TiO}_{2}$ until reaching $90 \mathrm{~g}$.

Dust properties

Figs. 1a, $1 \mathrm{~b}$ and $1 \mathrm{c}$ show three regions of the light spectrum representing the ultraviolet ray's region (UV), visible ray's region (VIS) and infrared ray's region (IR), respectively. The percentage of reflectance, transmittance and absorbance was measured using Maya 2000Pro spectrometers. The percentage value of reflectance in the wavelength range from $(376.8-816) \mathrm{nm}$ is $84.9 \%$, while the percentage of transmittance and observance is equal to $15 \%$ and $0.1 \%$, respectively. A scanning electron microscope (SEM) was used in order to examine the $\mathrm{TiO}_{2}$ sample distributed on the module and it was noted that the particles were non-homogenous. The diameter from different regions was then measured and it was found to range between (0.37-0.68) $\mu \mathrm{m}$ using the (Image J Software), as indicated in Fig .2. 

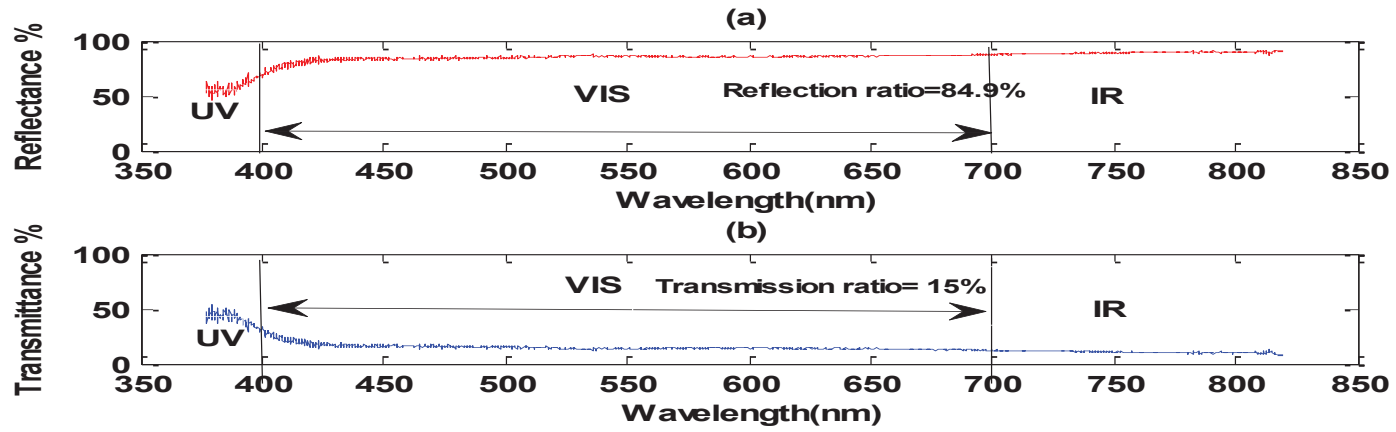

(c)

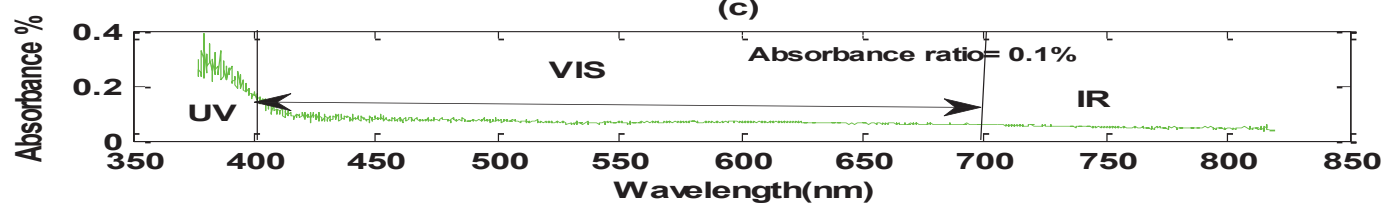

Fig.1 Spectroscopy of $\mathrm{TiO}_{2}$ (a) Reflectance (b) Transmittance and (c) Absorbance

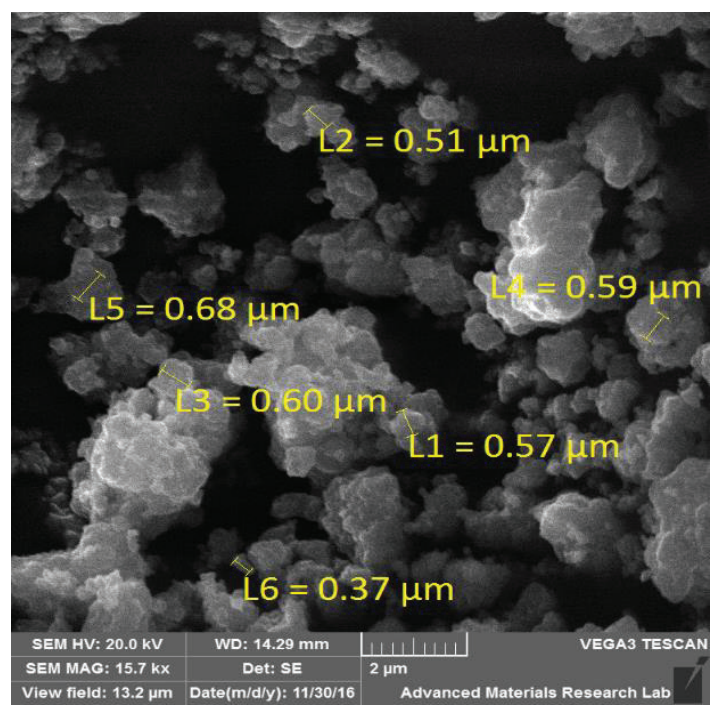

Fig.2. SEM images of $\mathrm{TiO}_{2}$

\section{Results and discussion}

Effect $\mathrm{TiO}_{2}$ on I-V and P-V characteristics

A I-V measurement is the best tool to provide more information on the overall performance of a PV module. Figs. $3 \mathrm{a}$ and $3 \mathrm{~b}$ present the current - voltage (I-V) and power - voltage (P-V) curves for the PV module under two conditions, namely clean and dusty conditions. It was found that titanium oxide deposition has a significant effect on the short circuit current of the panel. The current loss due to $\mathrm{TiO}_{2}$ was $85.4 \%$ where the dust density increased from $0-125 \mathrm{~g} / \mathrm{m}^{2}$. When the open circuit voltage of the dusty case was slightly lower than that of the clean case, the loss was $11.08 \%$. A $52.3 \mathrm{~W}$ drop in the maximum power as a result of the titanium 
oxide deposition was observed. The output of the maximum current $\left(\mathrm{I}_{\mathrm{m}}\right)$ and maximum voltage $\left(\mathrm{V}_{\mathrm{m}}\right)$ was also affected by the titanium accumulation. It was found that the current decreased from (3.011-0.44) A while the voltage decreased from (20.08-18.36) V. These results reflect on the efficiency of the PV performance, showing that the reduction in the efficiency was (19.2-2.4) \%. The studies carried out in Senegal have shown that the maximum power output loss can range from $18 \%$ to $78 \%$ respectively for the polycrystalline (ps-Si) and the monocrystalline module (mc-Si) where the modules were not cleaned following exposure to a Sahelian environment over the course of one year [18]. The outdoor studies conducted in Egypt have shown that the reduction of $\mathrm{P}_{\mathrm{m}}$ as a result of dust deposition could reach 35\% after two months without cleaning the PV modules [19].

(a) I-V Characterstics

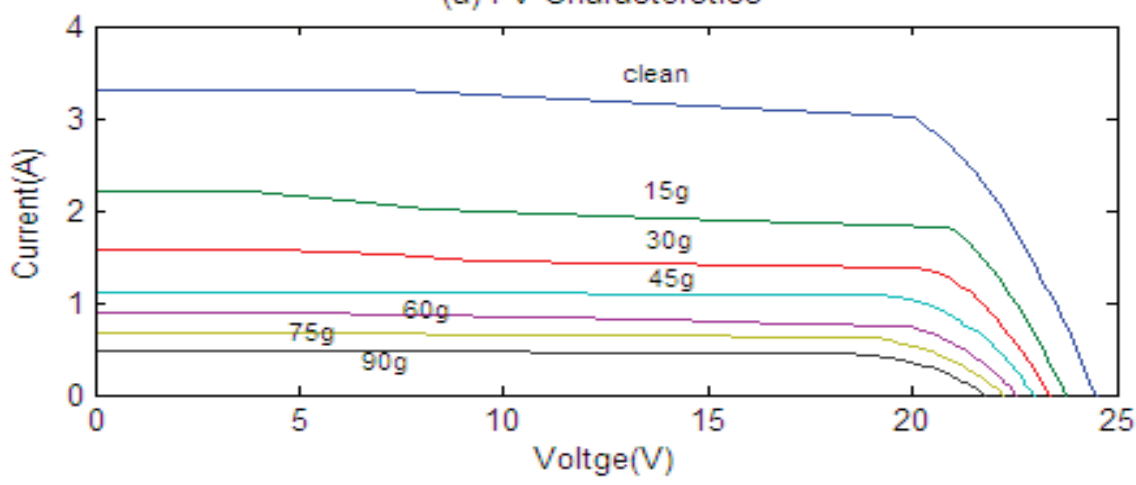

(b) P-V Characterstics

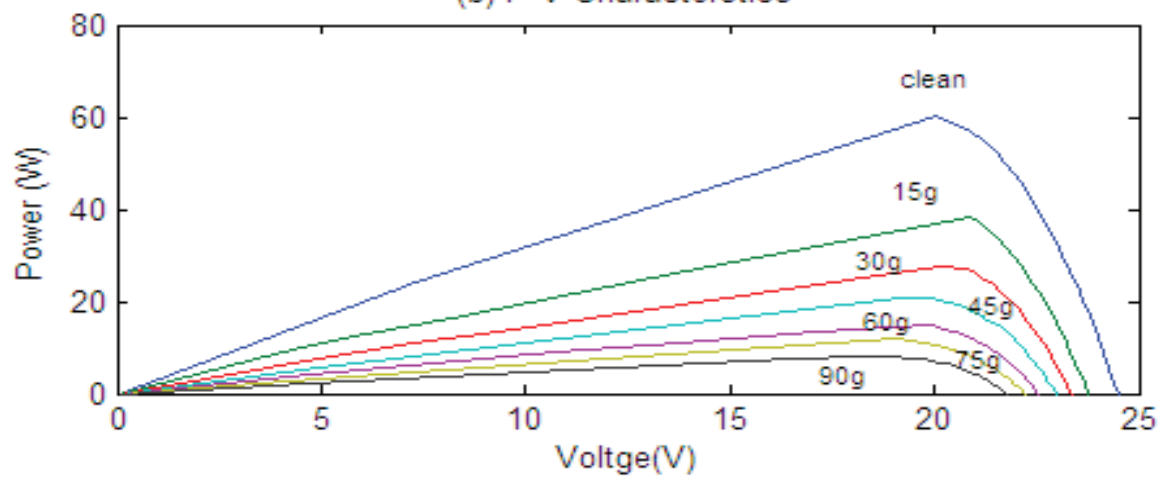

Fig.3. Comparison between the I-V and P-V characteristics of the PV module under clean and different density values of the masses for $\mathrm{TiO}_{2}$. 
Effect of $\mathrm{TiO}_{2}$ on the FF, $\mathrm{R}_{\mathrm{s}}, \mathrm{R}_{\mathrm{sh}}$ and $\mathrm{R}_{\max }$

The fill factor (FF) represents the squareness of the I-V curve and is mainly related to the resistive losses in a solar cell. Theoretically, in perfect cases, its value can be $100 \%$, corresponding to the square I-V curve. But it is not a suitable practice to square I-V. There are many losses which reduce the value of the fill factor which do not depend directly on the density mass of pollution. Dust obscures the amount of solar radiation that reaches the solar cells and it was observed that the increase in the amount of dust does not affect the value of the fill factor. As demonstrated in Fig .4 some strong fluctuations were observed in the FF, the maximum value was 0.80 and the minimum value was 0.72 at $62.5 \mathrm{~g} / \mathrm{m}^{2}$ and at $20 \mathrm{~g} / \mathrm{m}^{2}$ respectively, but in the clean case this was 0.74 and 0.77 at $125 \mathrm{~g} / \mathrm{m}^{2}$. This result is similar to the findings of Vorster who studied the relation between solar radiation and the fill factor using the PV concentrator array [20]. The fill factor can be mathematically written as a function of the open circuit voltage normalised $\left(v_{o c}\right)$ [21]
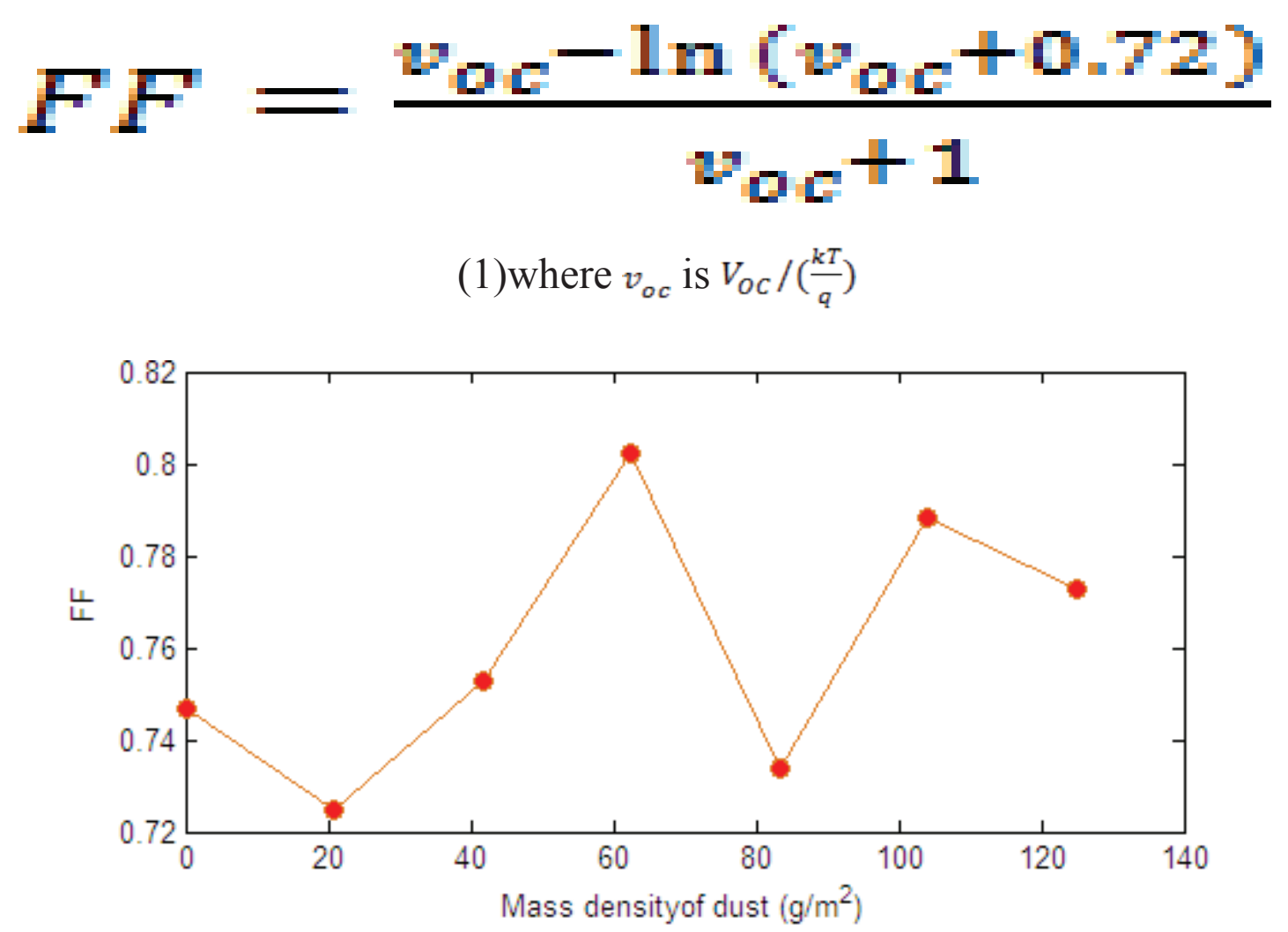

Fig.4 Fill factor versus density of mass 
In an ideal case only, the value of $(\mathrm{FF}=1)$ in relation to the $\mathrm{I}-\mathrm{V}$ curve of a solar cell is square, but the cell I-V curve actually behaves as exponential. Thus in the best possible case, the value of FF is less than one. These types of losses are classified into electrical losses and arise from the parasitic resistance, series $\left(R_{s}\right)$ and shunt resistance $\left(\mathrm{R}_{\mathrm{sh}}\right)$ of the cell. Such losses cannot be evaded or cannot be reduced beyond their fundamental limit. The series resistance represents the sum of the resistance values of all the components that come in the path of the current, while the shunt resistance is due to the leakage across the P-N junction. The maximum resistance $\left(R_{m}\right)$ represents the lesser value of resistance that yields maximum power $\left(\mathrm{P}_{\mathrm{m}}\right)$. The equation for the $\mathrm{R}_{\mathrm{m}}$ of the module can be written as $R_{m}=\mathrm{V}_{\mathrm{m}} / \mathrm{I}_{\mathrm{m}}$. It was found that the series resistance, shunt resistance and maximum resistance were increased from (1.4-7.7) $\Omega$, (43.77-341) $\Omega,(6.6-41.6) \Omega$ respectively, as shown in Figs. 5a, 5b and 5c. Nand et al. [22] noticed that the series resistance increases with a higher dust factor and shadow effects. 
(a)

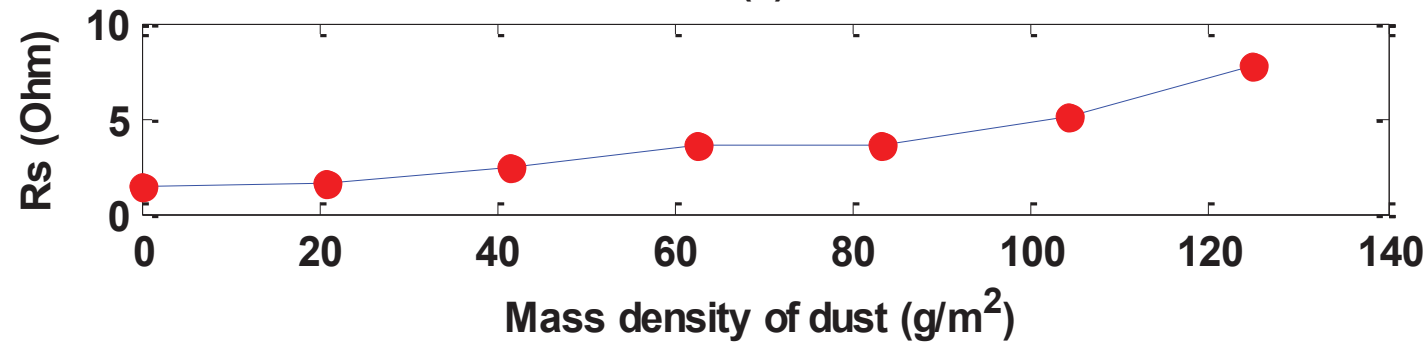

(b)

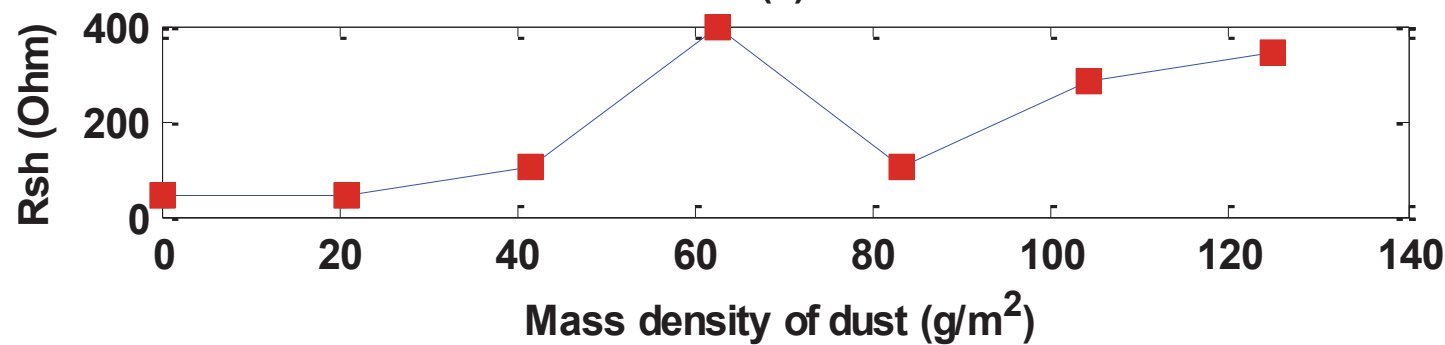

(c)

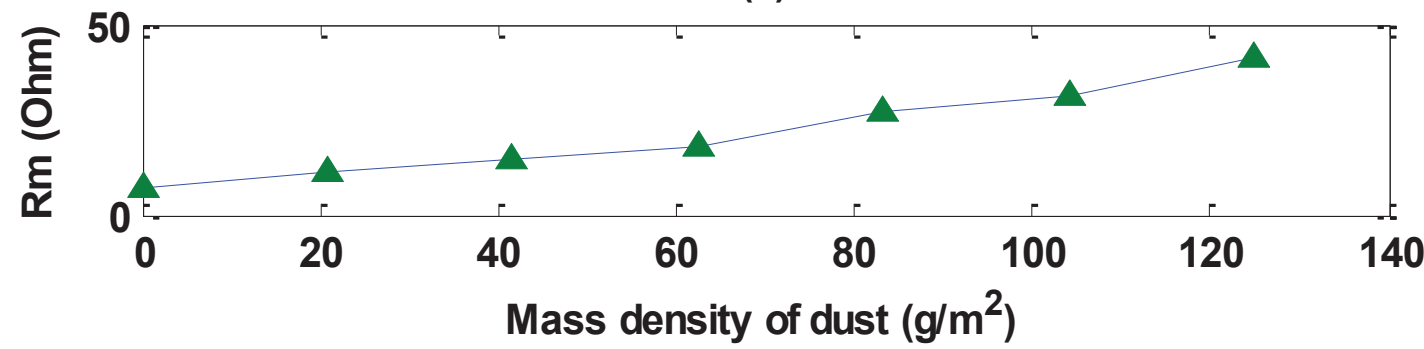

Fig.5 The effect of $\mathrm{TiO}_{2}$ on the (a) series resistance (b) shunt resistance and (c) maximum resistance.

Performance prediction model

Based on the experimental study, six electrical characteristics of a PV module have been selected and represented mathematically as follows: exponential function used to represent the short circuit current $\left(\mathrm{I}_{\mathrm{sc}}\right)$, maximum current $\left(\mathrm{I}_{\mathrm{m}}\right)$, maximum power $\left(\mathrm{P}_{\mathrm{m}}\right)$ and efficiency $(\mathrm{E})$, the Fourier function used to represent the open circuit voltage $\left(\mathrm{V}_{\mathrm{oc}}\right)$ and maximum voltage $\left(\mathrm{V}_{\mathrm{m}}\right)$. It was found in the literature that the researcher used the low-degree polynomial in order to simulate the dust deposition density so as to simulate the dust deposition on current, power efficiency etc. These correlations are valid for small values for dust deposition 
density. This problem was solved by using a polynomial of a higher degree, e.g. of the $7^{\text {th }}$ degree [23]. In order to reduce the number of coefficients which change from one case to another it was found that the exponential and Fourier functions are more efficient to represent the electrical parameters. Table 2 shows the function which was chosen to represent these parameters in this study.

Table 2: Implicit equations for electrical characteristics I, V, P and E with coefficients

\begin{tabular}{|c|c|}
\hline Gen & Coefficients\& Goodness of fit \\
\hline $\begin{array}{l}\text { Isc }=a^{*} \exp \left(b^{*} x\right) \quad+ \\
c^{*} \exp \left(d^{*} x\right)\end{array}$ & 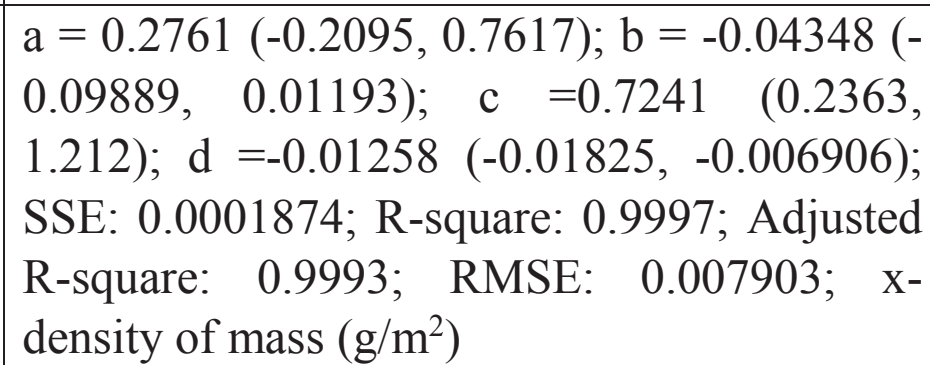 \\
\hline $\operatorname{Im}=$ & $\begin{array}{l}\mathrm{a}=0.9554(0.8559,1.055) ; \mathrm{b}=-0.01653(- \\
0.01967, \quad-0.01339) ; \text { SSE: } 0.009588 ; \quad \mathrm{R}- \\
\text { square: } 0.9818 ; \text { Adjusted R-square: } 0.9782 ; \\
\text { RMSE: } 0.04379 ; \mathrm{x} \text { - density of mass }\left(\mathrm{g} / \mathrm{m}^{2}\right)\end{array}$ \\
\hline $\begin{array}{l}\mathrm{Voc}=\mathrm{a} 0+\mathrm{a} 1 * \cos (\mathrm{x} * \mathrm{w}) \\
\mathrm{b} 1 * \sin (\mathrm{x} * \mathrm{w})\end{array}$ & $\begin{array}{l}\mathrm{a} 0=2.48 \mathrm{e}+005(-6.742 \mathrm{e}+012,6.742 \mathrm{e}+012) \\
\mathrm{a} 1=-2.48 \mathrm{e}+005(-6.742 \mathrm{e}+012,6.742 \mathrm{e}+012) \\
\mathrm{b} 1=277.3(-3.768 \mathrm{e}+009,3.768 \mathrm{e}+009) \mathrm{w}=- \\
\text { 3.897e-006 (-52.96, 52.96), SSE: 4.586e-005; } \\
\text { R-square: } 0.9948 ; \text { Adjusted R-square: 0.9896, } \\
\text { RMSE: } 0.00391\end{array}$ \\
\hline $\begin{array}{l}\mathrm{Vm}=\mathrm{a} 0+\mathrm{a} 1 * \cos (\mathrm{x} * \mathrm{w})+ \\
\mathrm{b} 1 * \sin (\mathrm{x} * \mathrm{w}) \\
\mathrm{a} 2 * \cos (2 * \mathrm{x} * \mathrm{w}) \\
\mathrm{b} 2 * \sin (2 * \mathrm{x} * \mathrm{w})\end{array}$ & $\begin{array}{l}\mathrm{a} 0=0.9772(0.8828,1.072), \mathrm{a} 1=0.01008 \\
(-0.1092,0.1294) \quad \mathrm{b} 1=0.0383(-0.07907, \\
0.1557), \mathrm{a} 2=0.009359(-0.151,0.1698) \mathrm{b} 2 \\
=0.03457(-0.1006,0.1698), \mathrm{w}=0.04179(- \\
0.00399,0.08757), \text { SSE: 0.0002826; R- } \\
\text { square: } 0.9726 ; \text { Adjusted R-square: } 0.8359,\end{array}$ \\
\hline
\end{tabular}




\begin{tabular}{|c|c|}
\hline & RMSE: $0.01681 ; \mathrm{x}-$ density of mass $\left(\mathrm{g} / \mathrm{m}^{2}\right)$ \\
\hline $\begin{array}{l}\mathrm{Pm}=\quad \mathrm{a}^{*} \exp \left(\mathrm{b}^{*} \mathrm{x}\right) \\
\mathrm{c}^{*} \exp \left(\mathrm{d}^{*} \mathrm{x}\right)\end{array}$ & $\begin{array}{l}\mathrm{a}=0.1677(0.05908,0.2764), \mathrm{b}=-0.1192(- \\
0.3147,0.07634) \quad \mathrm{c}=0.8323(0.7261 \text {, } \\
0.9385), \mathrm{d}=-0.0144 \quad(-0.01617,-0.01264) \\
\text { SSE: 0.000165; R-square: } 0.9997 \text {; Adjusted } \\
\text { R-square: } 0.9994 \quad \text { RMSE: } 0.007416 ; \quad \mathrm{x}- \\
\text { density of mass }\left(\mathrm{g} / \mathrm{m}^{2}\right)\end{array}$ \\
\hline $\begin{array}{c}E=a^{*} \exp \left(b^{*} x\right)+ \\
c^{*} \exp \left(d^{*} x\right)\end{array}$ & $\begin{array}{l}\mathrm{a}=0.6816(0.5735,0.7897), \mathrm{b}=0.002083 \\
(0.0008552,0.003311), \mathrm{c}=-0.6816(-0.7877, \\
-0.5755), \mathrm{d}=-0.03034 \quad(-0.03701,- \\
0.02367), \text { SSE: } 9.499 \mathrm{e}-005, \mathrm{R}-\mathrm{square}: 0.9998 \text {, } \\
\text { Adjusted R-square: } 0.9997, \mathrm{RMSE}: 0.005627 . \\
\mathrm{x}-\text { density of mass }\left(\mathrm{g} / \mathrm{m}^{2}\right)\end{array}$ \\
\hline
\end{tabular}

\section{Conclusion}

In this paper the effect of the titanium oxide accumulation on the performance of the PV module has been investigated. Titanium oxide is one of the dust components in the United Arab Emirates at different rates and in various locations. It was found that $\mathrm{TiO}_{2}$ has a significant effect on the short circuit current of the panel while the open circuit voltage is slightly lower than that the clean case, thus reflecting the maximum power and efficiency reduction. The parasitic resistance shunt and series resistances increased with the increasing density of mass in addition to the maximum resistance, which represents the maximum power value of the panel. Two functions were selected, namely the Fourier and the exponential functions with coefficients to represent six electrical characteristics.

\section{Acknowledgments}

The authors would like to honestly thank the National University of Malaysia for the provision of the grant TRGS/1/2014/UKM/01/11/1 to support this work. The authors are deeply grateful to Mr. Khamis Saeed Alkindi for consenting to the construction of the laboratory in his farm. Finally, thanks go to Mr. Mohammed 
Shameer, the supervisor of the Research Center for Advanced Materials, University of Sharjah for his for assistance in the analysis of dust samples using an electron microscope (SEM).

\section{References}

[1] S. E. Colesca and C. N. Ciocoiu, "An overview of the Romanian renewable energy sector," Renewable and sustainable energy reviews, vol. 24, pp. 149-158, 2013.

[2] J. Zhao, A. Wang, P. Campbell, and M. A. Green, "A 19.8\% efficient honeycomb multicrystalline silicon solar cell with improved light trapping," IEEE Transactions on Electron Devices, vol. 46, pp. 1978-1983, 1999.

[3] V. Tyagi, N. A. Rahim, N. Rahim, A. Jeyraj, and L. Selvaraj, "Progress in solar PV technology: research and achievement," Renewable and Sustainable Energy Reviews, vol. 20, pp. 443-461, 2013.

[4] S. Ghazi, A. Sayigh, and K. Ip, "Dust effect on flat surfaces-A review paper," Renewable and Sustainable Energy Reviews, vol. 33, pp. 742-751, 2014.

[5] A. Sayigh, "Effect of dust on flat plate collectors," in Sun: Mankind's Future Source of Energy, 1978, pp. 960-964.

[6] A. Sayigh, S. Al-Jandal, and H. Ahmed, "Dust effect on solar flat surfaces devices in Kuwait," in Proceedings of the workshop on the physics of non-conventional energy sources and materials science for energy, 1985, pp. 353-367.

[7] M. Mani and R. Pillai, "Impact of dust on solar photovoltaic (PV) performance: Research status, challenges and recommendations," Renewable and Sustainable Energy Reviews, vol. 14, pp. 3124-3131, 2010.

[8] J. Kaldellis, P. Fragos, and M. Kapsali, "Systematic experimental study of the pollution deposition impact on the energy yield of photovoltaic installations," Renewable Energy, vol. 36, pp. 2717-2724, 2011.

[9] T. Khatib, H. Kazem, K. Sopian, F. Buttinger, W. Elmenreich, and A. S. Albusaidi, "Effect of dust deposition on the performance of multi-crystalline photovoltaic modules based on experimental measurements," International Journal of Renewable Energy Research (IJRER), vol. 3, pp. 850-853, 2013.

[10] T. Sarver, A. Al-Qaraghuli, and L. L. Kazmerski, "A comprehensive review of the impact of dust on the use of solar energy: History, investigations, results, literature, and mitigation approaches," Renewable and Sustainable Energy Reviews, vol. 22, pp. 698-733, 2013.

[11] S. C. Costa, A. S. A. Diniz, and L. L. Kazmerski, "Dust and soiling issues and impacts relating to solar energy systems: Literature review update for 2012-2015," Renewable and Sustainable Energy Reviews, vol. 63, pp. 33-61, 2016.

[12] A. Ndiaye, A. Charki, A. Kobi, C. M. Kébé, P. A. Ndiaye, and V. Sambou, "Degradations of silicon photovoltaic modules: A literature review," Solar Energy, vol. 96, pp. 140-151, 2013. 
[13] J. K. Kaldellis, A. Kokala, and M. Kapsali, "Natural air pollution deposition impact on the efficiency of PV panels in urban environment," Fresenius Environmental Bulletin, vol. 19, pp. 2864-2872, 2010.

[14] M. R. Maghami, H. Hizam, C. Gomes, M. A. Radzi, M. I. Rezadad, and S. Hajighorbani, "Power loss due to soiling on solar panel: A review," Renewable and Sustainable Energy Reviews, vol. 59, pp. 1307-1316, 2016.

[15] Z. A. Darwish, H. A. Kazem, K. Sopian, M. Al-Goul, and H. Alawadhi, "Effect of dust pollutant type on photovoltaic performance," Renewable and Sustainable Energy Reviews, vol. 41, pp. 735-744, 2015.

[16] H. Garg, A. Shukla, I. Madhuri, R. Agnihotri, and S. Chakravertty, "Development of a simple low-cost solar simulator for indoor collector testing," Applied energy, vol. 21, pp. 43-54, 1985.

[17] Z. A. Darwish, K. Sopian, H. Alawadhi, H. A. Kazem, and M. Alghoul, "The impact of Calcium Carbonate on the photovoltaic performance: An indoor experimental study," International Journal of Applied Engineering Research, vol. 11, pp. 2091-2097, 2016.

[18] A. Ndiaye, C. M. Kébé, P. A. Ndiaye, A. Charki, A. Kobi, and V. Sambou, "Impact of dust on the photovoltaic (PV) modules characteristics after an exposition year in Sahelian environment: he case of Senegal," International Journal of Physical Sciences, vol. 8, pp.1166-1173, 2013.

[19] M. Ibrahim, B. Zinsser, H. El-Sherif, E. Hamouda, G. Makrides, G. E. Georghiou, et al., "Advanced Photovoltaic test park in Egypt for investigating the performance of different module and cell technologies," in Proceedings of the 24th Symposium Photovoltaic Solar Energy, Staffelstien, Germany, 2009.

[20] F. Vorster, E. Van Dyk, and A. Leitch, "Investigation on the IV characteristics of a high concentration, photovoltaic array," in Photovoltaic Specialists Conference, 2002. Record of the Twenty-Ninth IEEE, 2002, pp. 1604-1607.

[21] M. A. Green, "Accuracy of analytical expressions for solar cell fill factors," Solar Cells, vol. 7, pp. 37-340, 1982.

[22] N. Kishor, M. G. Villalva, S. R. Mohanty, and E. Ruppert, "Modeling of PV module with consideration of environmental factors," in ISGT Europe, 2010, pp. 1-5

[23] Z. A. Darwish, H. A. Kazem, K. Sopian, M. Alghoul, and H. Alawadhi, "Experimental investigation of dust pollutants and the impact of environmental parameters on PV performance: an experimental study," Environment, Development and Sustainability, pp. $1-20$. 